Article

\title{
Effects of Oxytetracycline and Gentamicin Therapeutic Doses on Hematological, Biochemical and Hematopoietic Parameters in Cyprinus carpio Juveniles
}

\author{
Elżbieta Kondera ${ }^{1}\left(\mathbb{D}\right.$, Bartosz Bojarski ${ }^{2, *}$, Katarzyna Lugowska ${ }^{1}$, Barbara Kot ${ }^{1}$ BD $_{\text {and }}$ \\ Małgorzata Witeska ${ }^{1}$ (D) \\ 1 Institute of Biological Sciences, Faculty of Exact and Natural Sciences, Siedlce University of Natural Sciences \\ and Humanities, Prusa 14 Street, 08-110 Siedlce, Poland; elzbieta.kondera@uph.edu.pl (E.K.); \\ katarzyna.lugowska@uph.edu.pl (K.Ł.); barbara.kot@uph.edu.pl (B.K.); \\ malgorzata.witeska@uph.edu.pl (M.W.) \\ 2 Institute of Ichthyobiology and Aquaculture in Gołysz, Polish Academy of Sciences, \\ Kalinowa 2, 43-520 Chybie, Poland \\ * Correspondence: bbojarski@o2.pl
}

Received: 23 October 2020; Accepted: 30 November 2020; Published: 3 December 2020

check for updates

Simple Summary: Hematological, biochemical and hematopoietic effects of therapeutic doses of oxytetracycline (OTC) and gentamicin (GEN) in clinically healthy common carp juveniles were studied. The fish were divided into four groups: controls 1 and 2 (untreated or injected with $0.6 \% \mathrm{NaCl}$ solution), and two groups treated with antibiotics (orally with OTC four times every two days or injected with a single dose of GEN dissolved in $0.6 \% \mathrm{NaCl}$ ). Blood and head kidneys were sampled from all fish 3 days post-treatments for hematological, biochemical and hematopoietic tissue analyses. The obtained results showed no considerable hematotoxicity or hepatotoxicity of therapeutic doses of OTC and GEN to carp.

Abstract: Hematological, biochemical and hematopoietic effects of therapeutic doses of two antibiotics, oxytetracycline (OTC) and gentamicin (GEN), in clinically healthy common carp juveniles were studied. The fish were divided into four groups: controls 1 and 2 (untreated or injected with $0.6 \% \mathrm{NaCl}$ solution), and two groups treated with antibiotics (orally with $75 \mathrm{mg} / \mathrm{kg}$ OTC four times every two days or injected with a single dose $(4 \mathrm{mg} / \mathrm{kg}$ ) of GEN dissolved in $0.6 \% \mathrm{NaCl})$. Blood and head kidneys were sampled from all fish 3 days post-treatments for hematological, biochemical and hematopoietic tissue analyses. No major alterations in the values of hematological and serum biochemical parameters occurred following administration of OTC or GEN. Glucose concentrations were significantly lower in both groups of fish subjected to injections (Control 2 and GEN), while the oxidative metabolic activity of phagocytes increased in the antibiotic-treated groups (significantly in OTC). More alterations were observed in hematopoietic tissue. Immunocytochemical analysis revealed that $\mathrm{G}$ caused a significant increase in the rate of cell proliferation (PCNA-positive cells) and an increase in the frequency of apoptotic cells (caspase-positive). The frequency of lymphoid lineage decreased, which was related to a decrease in the abundance of mature lymphocytes in GEN-treated fish. Percentages of neutrophilic lineage were significantly elevated in OTC and GEN groups compared to controls. The obtained results showed no considerable hematotoxicity or hepatotoxicity of therapeutic doses of OTC and GEN to carp.

Keywords: antibiotics; erythrocytes; head kidney; hepatic aminotransferases; fish; leukocytes; toxicity 


\section{Introduction}

Fish rearing under high stocking densities is accompanied by increased risk of infectious bacterial diseases that are treated mainly with antibiotics. Oxytetracycline (OTC) is often employed in fish farms to treat or prevent bacterial infections [1] and is one of the most used antibiotics in aquaculture [2]. Gentamicin (GEN) is an aminoglycoside antibiotic commonly used in veterinary medicine against a variety of infections caused by Gram-positive and Gram-negative aerobic bacteria and sometimes applied in fishery practice [3]. Aminoglycosides are also used in prophylaxis or as growth promoters for farm animals [4]. The presence of aminoglycosides in fresh water and sediments was reported in Polish rivers and lakes [5]. Irrational use of antibiotics accelerated the spread of antibiotic resistant bacteria across the globe [6]. Antibiotics at significant concentrations in aquatic environments are the principal source of selective pressure for antimicrobial resistance in bacteria because susceptible bacteria in the sediment and water are replaced by resistant ones [7], while antibiotics at subinhibitory concentrations may stimulate mutagenesis and horizontal transfer of antibiotic resistance genes (ARGs) for human pathogens, which may result in decreased efficacy of different antibiotic groups and severely limits the therapeutic options in human infections [8,9]. OTC is an antibiotic belonging to the tetracycline class. In fish farm environments where oxytetracycline was used, higher prevalence of tetracycline resistance $($ tet $R)$ genes was showed than in those in which this antibiotic was not applied [10,11].

Moreover, OTC and GEN may show adverse effects on target organisms. Elia et al. [1] reported disturbances in the hepatic and renal antioxidant systems in Cyprinus carpio treated with 150 and $300 \mathrm{mg} / \mathrm{kg}$ of OTC, while the therapeutic dose $(75 \mathrm{mg} / \mathrm{kg})$ caused only minor changes-an increase in glutathione peroxidase and glutathione reductase activities. Hepatic and renal histopathological changes were observed by Reda et al. [12] in Oreochromis niloticus fed for 12 weeks diet containing $100 \mathrm{mg} / \mathrm{kg}$ of OTC. Histopathological alterations in the gills and liver of Oncorhynchus mykiss after acute exposure to OTC ( $96 \mathrm{~h}: 0.005-50 \mathrm{mg} / \mathrm{L}$ ) were reported by Rodrigues et al. [13]. According to Grondel et al. [14], OTC delayed mitogenic response of phytohaemagglutinin-stimulated pronephric lymphocytes in Cyprinus carpio. Botelho et al. [15] reported a genotoxic effect of waterborne environmentally realistic OTC levels $(4-16 \mu \mathrm{g} / \mathrm{L})$ in Oreochromis niloticus. Mild oxidative effect and genotoxic damage was reported in OTC-treated Oncorhynchus mykiss by Rodrigues et al. [16]. It was confirmed by the results obtained by Pes et al. [17] who reported oxidative stress in Rhamdia quelen fed for 21 days with feed containing $0.1 \mathrm{~g} / \mathrm{kg}$ of OTC. The fish showed increased lipid and protein peroxidation accompanied by an increase in activities of superoxide dismutase, glutathione peroxidase and glutathione reductase. Oxytetracycline caused delayed hatching of Danio rerio embryos, inhibited catalase and induced glutathione-S-transferase and lactate dehydrogenase activities in adults [18]. The larvae of Danio rerio exposed to $125-1500 \mathrm{mg} / \mathrm{L}$ of OTC showed a dose-dependent increase in neutrophil count, indicating an inflammatory response [19]. Various hematological effects of OTC were also reported but the results of various studies are contradictory. Omoregie and Oyebani [20] observed dose-dependent anemia, leukopenia and throbocytopenia in Oreochromis niloticus fed for 8 weeks with feed containing $0.63-5 \%$ OTC. Leukopenia with neutropenia were observed in Oncorhynchus mykiss fed $2.5 \mathrm{~g} / \mathrm{kg}$ of OTC [21]. Neutropenia and monocytosis occurred in Oncorhynchus mykiss after injection of $20 \mathrm{mg} / \mathrm{kg}$ of OTC [22]. Increases in the values of hemoglobin concentration, hematocrit and leukocyte count accompanied by a decrease in erythrocyte count were reported by Ambili et al. [23] in Labeo rohita exposed to waterborne OTC ( $80 \mathrm{mg} / \mathrm{L})$ for 25 days. No alterations in most hematological values except for a decrease in hematocrit and thrombocyte count were observed in Oreochromis niloticus fed a diet containing $500 \mathrm{mg} / \mathrm{kg}$ of OTC for 2 weeks [24]. No changes in the values of most hematological parameters and thrombocytosis in the same species fed a similar diet for 60 days were reported by El-Adawy et al. [25]. A short-term increase in erythrocyte and leukocyte counts in Sparus aurata after dietary administration of $75 \mathrm{mg} / \mathrm{kg}$ of OTC for 10 days was reported by Serezli et al. [26]. OTC-induced alterations in plasma biochemical profile included increases in the activities of hepatic alanine aminotransferese (ALT) and aspartate aminotransferase (AST) $[21,25,27]$. 
The main limitation of gentamicin use is its potential nephrotoxicity [28]. Reimschuessel et al. [29] reported progressive necrosis of proximal renal tubules of Opsanus tau in 2-8 days after intraperitoneal or intramuscular injection of $2.5-50 \mathrm{mg} / \mathrm{kg}$ of GEN. However, in Carassius auratus, regeneration of injured nephrons and entirely new nephrons were observed within 2-3 weeks after injection of $50 \mathrm{mg} / \mathrm{kg}$ of GEN [30]. Oreochromis nilotica showed acute tubular necrosis after intraperitoneal injection of 5 or $25 \mathrm{mg} / \mathrm{kg}$ of GEN followed by regeneration of epithelial cells of damaged tubules and the development of new nephrons [31]. According to Chen et al. [32], GEN (36 mg/kg) induced significant changes in the trunk kidney, liver, and intestine accompanied by anemia (reduced hematocrit and erythrocyte count) in Oreochromis nilotica. Gentamicin-treated fish also showed reduced levels of plasma sodium, chloride, calcium and iron, decreased total protein and cholesterol levels and hyperglycemia, accompanied by considerably elevated activities of alanine aminotransferase, aspartate aminotransferase, and creatine kinase. The data obtained by Cernaro et al. [28] revealed tubular degeneration with loss of the cellular apical brush border, necrosis and hyaline inclusions in the cytoplasm of renal tubule epithelial cells of Danio rerio injected with $0.4 \mathrm{mg}$ of GEN. Exposure to $0.001 \%$ gentamicin sulfate solution for $24 \mathrm{~h}$ induced damage to the lateral line neuromasts of Astyanax fasciatus and Danio rerio [33].

The available data on hematological effects of oxytetracycline and gentamicin in fish are scarce and ambiguous, and nothing is known about the possible effects of these antibiotics on hematopoietic processes. Therefore, in the present study the issue of hematological and hematopoietic effects of therapeutic doses of these antibiotics used in healthy juvenile common carp was undertaken to broaden the knowledge of their possible adverse side effects.

\section{Materials and Methods}

Common carp Cyprinus carpio L. healthy juveniles of body mass $65.8 \pm 7.6 \mathrm{~g}$ and body length $14.7 \pm 6.1 \mathrm{~cm}$ were harvested from the rearing ponds of the Inland Fisheries Institute in Żabieniec, Poland in autumn and transferred in plastic bags with water and pure oxygen to the laboratory of the Department of Animal Physiology, Siedlce University of Natural Sciences and Humanities. The fish were stocked into the flow-through aerated $300 \mathrm{~L}$ tank supplied with fresh nonchlorinated tap water (initial temperature $12{ }^{\circ} \mathrm{C}$ and oxygen concentration $9.0 \mathrm{mg} / \mathrm{L}$ ) and acclimated for 3 months during which the temperature was gradually raised to $17.5^{\circ} \mathrm{C}$, the oxygen concentration was $7.6-8.5 \mathrm{mg} / \mathrm{L}$, the $\mathrm{pH}$ was $7.0-7.5$, and ammonium and nitrite were $0.0 \mathrm{mg} / \mathrm{L}$. During the acclimation period, the fish were fed once a day to satiation with pellets Aller Aqua Classic $4 \mathrm{~mm}$ diameter (containing $30 \%$ protein, $7 \%$ lipid, $43 \%$ carbohydrate, $7 \%$ ash, $5 \%$ fiber and with a calorific value of $433 \mathrm{kcal} / 100 \mathrm{~g}$ ). Before the experiment, 40 fish were randomly transferred to 4 aerated glass aquaria of $100 \mathrm{~L}$ volume, 10 fish in each and left for a week to habituate. During this time, the fish were fed with Aller Aqua Classic $4 \mathrm{~mm}$ pellets (Aller Aqua, Golub-Dobrzyń, Poland) once a day in the morning at the rate of $1 \%$ of body mass. Every day, about $3 \mathrm{~h}$ post feeding, $3 / 4$ of water was gently siphoned out so as not to disturb fish and immediately replaced with fresh tap water to maintain appropriate water quality.

After the period of habituation, the fish from groups Control 1 and 2, and GEN, were fed as previously described. The fish from group OTC were fed every 2 days (4 times) with Aller Aqua Classic $4 \mathrm{~mm}$ pellets mixed with an oxytetracycline hydrochloride preparation dedicated to fish (Ichtioxan, Biofaktor, Skierniewice, Poland) at the dose of $75 \mathrm{mg} / \mathrm{kg}$. OTC was administered according to the producer's protocol. Ichtioxan contains $750 \mathrm{mg} / \mathrm{g}$ of powdered oxytetracycline hydrochloride, therefore to obtain recommended therapeutic dose of $75 \mathrm{mg} / \mathrm{kg}$, $100 \mathrm{mg}$ of Ichtioxan per $1 \mathrm{~kg}$ of fish mass was used. Briefly, a preweighed amount of pellets (1\% of fish mass) was soaked in about $5 \mathrm{~mL}$ of aqueous solution containing $65.8 \mathrm{mg}$ of Ichtioxan, gently mixed and dried at $50^{\circ} \mathrm{C}$. A similar method of OTC oral administration was described by Trushenski et al. [34], while the results obtained by Hassani et al. [35] showed that OTC is thermostable. On every second day, the fish from the OTC group obtained plain feed. On the day 8 , the Control 2 fish were intraperitoneally injected with a single dose of sterile $0.6 \% \mathrm{NaCl}$ solution, while GEN fish were intraperitoneally injected with a single dose 
$(4 \mathrm{mg} / \mathrm{kg}$ ) of gentamicin (Biowet, Puławy, Poland) dissolved in $0.6 \% \mathrm{NaCl}$ solution. No therapeutic GEN dosage for cyprinid fish was found in the literature (however, in fishery practice single injections of 4-5 mg/kg are often used); therefore, the dose was established based on the reports by Jones et al. [36] and Bojarski et al. [3] who applied $3.5 \mathrm{mg} / \mathrm{kg}$ or $5 \mathrm{mg} / \mathrm{kg}$ of GEN to Carassius auratus and Carassius gibelio, respectively, in a single injection. Three days after the end of treatments (feeding OTC and injections) blood and head kidneys were sampled from all fish. A time of three days post treatments was left to develop reaction to antibiotics, particularly in the hematopoietic system.

Water quality parameters during habituation and the experimental period were measured every day (temperature, oxygen concentration) or every 3 days ( $\mathrm{pH}$, ammonium and nitrite concentrations). Temperature and oxygen level were measured using an oxygen meter (HI 9143, Hanna Instruments, Woonsocket, RI, USA), pH with a pH-meter (N5123, Elwro, Wrocław, Poland), and nitrogenous metabolites using colorimetric Visocolor kits (Visocolor Eco Ammonium 3 and Visocolor Eco Nitrite, Macherey Nagel, Düren, Germany). During the habituation and experimental periods, water temperature was $18.0-19.5{ }^{\circ} \mathrm{C}, \mathrm{O}_{2}$ concentration 7.1-7.5 mg/L, pH 7.3-7.6, ammonium 0.05 mg/L and nitrite $0.0 \mathrm{mg} / \mathrm{L}$.

Blood was sampled from live fish by heart puncture with heparinized needles to heparinized Eppendorf tubes ( 2 tubes per fish $-500 \mu \mathrm{L}$ of blood for plasma to evaluate hepatic enzyme activities, and $200 \mu \mathrm{L}$ for remaining hematological and biochemical analyses). The following analyses were performed using fresh full blood: hematocrit (Ht), erythrocyte count (RBC), measurement of hemoglobin concentration $(\mathrm{Hb})$, calculations of mean cell volume $(\mathrm{MCV})$, mean corpuscular hemoglobin $(\mathrm{MCH})$ and mean corpuscular hemoglobin concentration (MCHC), leukocyte count (WBC), measurement of oxidative metabolic activity of phagocytes (NBT), measurement of plasma glucose. Blood smears were also made to evaluate blood cell morphology. Activities of alanine aminotransferase (ALT) and aspartate aminotransferase (AST) were measured in plasma. Hematocrit was measured using the microhematocrit method after centrifugation of capillaries with blood. Erythrocyte and leukocyte counts were performed in Bürker hemocytometers (Paul Marienfeld GmbH \& Co. KG, Lauda-Königshofen, Germany) in blood diluted 100 times with Hayem solution. Hemoglobin concentration was measured spectrophotometrically at $540 \mathrm{~nm}$ wavelength after the mixing of blood with Drabkin solution and the conversion of hemoglobin to cyanmethemoglobin. $\mathrm{Hb}$ values were calculated from the equation of the relationship between dilutions of hemoglobin standard and their extinction. $\mathrm{MCV}, \mathrm{MCH}$ and $\mathrm{MCHC}$ were calculated using $\mathrm{Ht}, \mathrm{Hb}$ and $\mathrm{RBC}$ values using standard formulas [37]. Glucose concentration was measured using an Accu Check (Roche, Basel, Switzerland) glucometer. Oxidative metabolic activity of phagocytes (NBT) was measured spectrophotometrically at $546 \mathrm{~nm}$ wavelength using the nitrotetrazolium blue reduction method adopted for fish blood [38]. ALT and AST activities were measured spectrophotometrically at $340 \mathrm{~nm}$ wavelength in blood plasma obtained by blood centrifugation and using Pointe Scientific kits (Pointe Scientific, Warsaw, Poland), according to the producer's protocol. Blood smears were stained using May-Grünwald and Giemsa solutions and fixed with Histokitt (Carl Roth, Karlsruhe, Germany) and cover slips. They were inspected using a Nikon Eclipse E600 light microscope (Nikon, Tokyo, Japan) at 400× magnification. In each smear, 300 erythrocytes, 100 leukocytes and the number of thrombocytes accompanying the 100 leukocytes were counted. Percentage of erythroblasts and abnormal erythrocytes, differential leukocyte count (percentage of lymphocytes, neutrophils and monocytes), thrombocyte count (TC) based on the number of thrombocytes in smear per 100 leukocytes and WBC values were calculated.

Then, all fish were euthanized with MS-222 (Sigma-Aldrich, Poznań, Poland) overdose and decapitated. Head kidneys were isolated and hematopoietic tissue preparations were made. The surface of isolated fresh organs was blotted, and then tissue was gently smeared on degreased slides. After being dried at room temperature for $24 \mathrm{~h}$, the smears were stained using May-Grünwald and Giemsa solutions. Then, the smears were viewed using a light microscope (Nikon Eclipse microscope 300, at $1000 \times$ magnification, Nikon Corporation, Tokyo, Japan) to evaluate cellular structure of hematopoietic tissue. Percentages of all types of hematopoietic precursor cells (22 types of cells) 
were calculated per 500 cells inspected in each smear, according to Fijan [39,40] and Kondera [41]. The identified cells were then grouped into the main cell lineages (erythroid, lymphoid, neutrophilic, monocytoid, basophilic, eosinophilic, thrombocytoid), most of which included various developmental stages. Early blast cells of various lineages were morphologically similar, so they were included in one common group to avoid identification bias. Cells of unclear characteristics were placed into the group of unclassified cells. Fields with crowded, deformed, damaged cells were excluded. Areas of kidney tissue with numerous mature erythrocytes (possibly blood vessel contents) were also ignored.

The other smears were stained using immunocytochemical methods to visualize PCNA-positive cells (indicating proliferative activity) and caspase 3-positive cells (indicating apoptotic activity). The presence of PCNA was detected using rabbit monoclonal anti-PCNA antibodies (Dako, Carpinteria, CA, USA) and visualized using the Dako rabbit PCNA Envision system. The presence of caspase 3 was detected with mouse anti-caspase 3 active antibodies (Sigma-Aldrich, Poznań, Poland), and visualized using the Dako mouse anti-caspase Envision system. The reagents were used according to the producer's protocols. The PCNA-positive and caspase 3-positive cells stained brownish and were easily distinguishable from other cells (stained light blue with hematoxylin). Percentages of proliferating (PCNA-positive) and apoptotic (caspase 3-positive) precursor cells were counted in at least 6 fields per 300 inspected hematopoietic cells, and the hematopoietic cell turnover rate was calculated as the PCNA/caspase 3 ratio.

The results were subjected to statistical analysis using Statistica 12 (Dell Technologies, Round Rock TX, USA). Mean values and standard deviations were calculated for the values of all parameters in the experimental groups and the Shapiro-Wilk test was used to evaluate the normality of distribution. As most parameters showed normal distribution, one-way ANOVA followed by Duncan's post-hoc test were performed to evaluate significance of differences in the values of parameters among the groups (assuming significance level $p \leq 0.05$ ).

The study was performed according to the Act on the Protection of Animals Used for Scientific and Educational Purposes and with the consent of the Local Ethics Committee in Warsaw (No-767/2018).

\section{Results}

No major alterations in the values of hematological parameters occurred following administration of OTC or GEN and no significant differences were observed among the experimental groups (Table 1). Antibiotics did not significantly alter the activities of hepatic aminotransferases ALT and AST; however, in groups exposed to antibiotics the results were much more variable and the mean values were higher compared to the controls. The only significant differences were observed in the values of plasma glucose level and NBT. Glucose concentrations were significantly lower in both groups of fish subjected to injections (Control 2 and GEN), while NBT values were elevated in antibiotic-treated groups (significantly in OTC).

Antibiotic treatments resulted also in some significant changes in the head kidney hematopoietic tissue of carp (Table 2). Immunocytochemical analysis revealed that GEN caused a significant increase in the rate of cell proliferation (PCNA-positive cells) (Figure 1A) compared to Control 2, and an increase in the frequency of apoptotic cells (caspase 3-positive) (Figure 1B) compared to both Control 1 and 2. Mean frequencies of proliferating and apoptotic cells in the OTC group were higher compared to the Controls, but the differences were statistically insignificant. No significant differences occurred in the cell turnover rate measured as the ratio of proliferating to apoptotic cells (PCNA/caspase 3). In addition, no significant differences occurred in the percentages of most cell lineages, among which only the frequency of lymphoid and neutrophilic cells significantly changed. The frequency of lymphoid lineage in GEN group was significantly lower compared to the Control 1, which was related to a decrease in the abundance of mature lymphocytes. Percentages of neutrophilic lineage were significantly elevated in both OTC and GEN groups which resulted mainly from an increase in the abundance of immature neutrophils (myelocytes and metamyelocytes) (Figure 1C). The frequency of mature 
(band and segmented) neutrophils significantly increased only in the GEN group compared to the related Control 2.

Table 1. The effects of oxytetracycline and gentamicin on the hematological and biochemical parameters in common carp (Control 1-untreated, Control 2-injected with $0.6 \% \mathrm{NaCl}$, OTC - fed oxytetracycline 4 times every 2 days at $75 \mathrm{mg} / \mathrm{kg}$, G-injected with single dose $50 \mathrm{mg} / \mathrm{kg}$ gentamicin in $0.6 \% \mathrm{NaCl}$, different letter superscripts indicate statistically significant differences among groups, $n=10$, Duncan post-hoc test, $p \leq 0.05$ ).

\begin{tabular}{|c|c|c|c|c|}
\hline \multirow{2}{*}{ Parameter } & \multicolumn{4}{|c|}{ Experimental Groups } \\
\hline & Control 1 & Control 2 & OTC & G \\
\hline $\mathrm{Ht}[\%]$ & $30.7 \pm 3.4^{\mathrm{a}}$ & $33.4 \pm 3.2^{\mathrm{a}}$ & $32.7 \pm 3.8^{a}$ & $30.9 \pm 4.0^{\mathrm{a}}$ \\
\hline $\mathrm{Hb}[\mathrm{g} / \mathrm{L}]$ & $84.8 \pm 13.0^{\mathrm{a}}$ & $98.1 \pm 13.2^{\mathrm{a}}$ & $89.4 \pm 10.4^{\mathrm{a}}$ & $93.5 \pm 7.5^{\mathrm{a}}$ \\
\hline $\mathrm{RBC}\left[10^{6} / \mu \mathrm{L}\right]$ & $1.60 \pm 0.14^{\mathrm{a}}$ & $1.71 \pm 0.31^{\mathrm{a}}$ & $1.74 \pm 0.24^{\mathrm{a}}$ & $1.65 \pm 0.13^{a}$ \\
\hline MCV [fL] & $193.0 \pm 28.9^{\mathrm{a}}$ & $199.0 \pm 29.6^{\mathrm{a}}$ & $190.6 \pm 25.2^{\mathrm{a}}$ & $188.4 \pm 25.8^{\mathrm{a}}$ \\
\hline $\mathrm{MCH}[\mathrm{pg}]$ & $53.4 \pm 9.8^{a}$ & $58.5 \pm 9.6^{\mathrm{a}}$ & $52.2 \pm 7.8^{a}$ & $57.1 \pm 6.2^{\mathrm{a}}$ \\
\hline $\mathrm{MCHC}[\mathrm{g} / \mathrm{L}]$ & $276.0 \pm 19.6^{a}$ & $293.7 \pm 29.2^{\mathrm{a}}$ & $274.5 \pm 23.9^{a}$ & $306.6 \pm 43.9^{\mathrm{a}}$ \\
\hline Erythroblasts [\%] & $0.1 \pm 0.2^{\mathrm{a}}$ & $0.2 \pm 0.2^{\mathrm{a}}$ & $0.2 \pm 0.2^{\mathrm{a}}$ & $0.1 \pm 0.2^{\mathrm{a}}$ \\
\hline Abnormal erythrocytes [\%] & $3.2 \pm 2.4^{\mathrm{a}}$ & $2.9 \pm 2.4^{\mathrm{a}}$ & $2.4 \pm 2.2^{\mathrm{a}}$ & $2.7 \pm 2.2^{\mathrm{a}}$ \\
\hline $\mathrm{WBC}\left[10^{3} / \mu \mathrm{L}\right]$ & $77.0 \pm 25.7^{\mathrm{a}}$ & $57.9 \pm 21.0^{\mathrm{a}}$ & $69.9 \pm 19.7^{a}$ & $62.9 \pm 21.4^{\mathrm{a}}$ \\
\hline Lymphocytes [\%] & $96.0 \pm 5.8^{\mathrm{a}}$ & $97.0 \pm 3.6^{\mathrm{a}}$ & $95.8 \pm 3.9^{\mathrm{a}}$ & $93.7 \pm 5.0^{\mathrm{a}}$ \\
\hline Neutrophils [\%] & $1.6 \pm 2.1^{\mathrm{a}}$ & $2.0 \pm 3.3^{\mathrm{a}}$ & $2.5 \pm 2.6^{\mathrm{a}}$ & $4.9 \pm 6.0^{\mathrm{a}}$ \\
\hline Monocytes [\%] & $1.8 \pm 4.0^{\mathrm{a}}$ & $0.7 \pm 0.8^{a}$ & $0.9 \pm 1.0^{\mathrm{a}}$ & $1.1 \pm 1.4^{\mathrm{a}}$ \\
\hline TC $\left[10^{3} / \mu \mathrm{L}\right]$ & $5.4 \pm 7.7^{\mathrm{a}}$ & $4.2 \pm 5.6^{\mathrm{a}}$ & $4.7 \pm 6.0^{\mathrm{a}}$ & $5.4 \pm 6.3^{a}$ \\
\hline Glucose [mg/dL] & $65.3 \pm 7.2^{\mathrm{a}}$ & $54.7 \pm 8.0^{b}$ & $70.2 \pm 8.5^{\mathrm{a}}$ & $55.1 \pm 12.4^{b}$ \\
\hline NBT [g/L] & $0.69 \pm 0.21^{\mathrm{a}}$ & $0.77 \pm 0.17^{\mathrm{a}}$ & $1.49 \pm 0.18^{b}$ & $1.03 \pm 0.27^{\mathrm{ab}}$ \\
\hline ALT [U/L] & $74.0 \pm 13.8^{\mathrm{a}}$ & $57.5 \pm 14.9^{a}$ & $81.1 \pm 38.7^{a}$ & $70.0 \pm 31.8^{a}$ \\
\hline AST [U/L] & $67.0 \pm 8.9^{\mathrm{a}}$ & $65.4 \pm 27.4^{\mathrm{a}}$ & $86.0 \pm 51.1^{\mathrm{a}}$ & $91.1 \pm 68.0^{\mathrm{a}}$ \\
\hline
\end{tabular}

Table 2. The effects of oxytetracycline and gentamicin on the proliferative and apoptotic activity and cellular composition of hematopoietic tissue in common carp (Control 1-untreated, Control 2-injected with $0.6 \% \mathrm{NaCl}$, OTC—fed oxytetracycline 4 times every 2 days at $75 \mathrm{mg} / \mathrm{kg}$, $\mathrm{G}$-injected with single dose $50 \mathrm{mg} / \mathrm{kg}$ gentamicin in $0.6 \% \mathrm{NaCl}$, different letter superscripts indicate statistically significant differences among groups, $n=10$, Duncan post-hoc test, $p \leq 0.05$ ).

\begin{tabular}{|c|c|c|c|c|}
\hline \multirow{2}{*}{ Cell Types } & \multicolumn{4}{|c|}{ Experimental Groups } \\
\hline & Control 1 & Control 2 & OTC & G \\
\hline PCNA-positive [\%] & $7.6 \pm 1.3^{\mathrm{ab}}$ & $7.4 \pm 1.2^{\mathrm{a}}$ & $8.5 \pm 1.7^{\mathrm{ab}}$ & $9.5 \pm 1.9^{b}$ \\
\hline Cas-positive [\%] & $6.9 \pm 1.1^{\mathrm{a}}$ & $6.5 \pm 1.3^{a}$ & $8.1 \pm 1.7^{\mathrm{ab}}$ & $8.8 \pm 1.5^{b}$ \\
\hline PCNA/Cas & $1.2 \pm 0.4^{\mathrm{a}}$ & $1.2 \pm 0.3^{\mathrm{a}}$ & $1.1 \pm 0.4^{\mathrm{a}}$ & $1.1 \pm 0.2^{\mathrm{a}}$ \\
\hline Early blast cells & $8.9 \pm 2.8^{a}$ & $8.9 \pm 2.6^{a}$ & $9.9 \pm 2.8^{a}$ & $10.7 \pm 3.2^{\mathrm{a}}$ \\
\hline Erythroid [\%] & $6.2 \pm 1.6^{\mathrm{a}}$ & $6.4 \pm 1.6^{\mathrm{a}}$ & $7.5 \pm 1.7^{\mathrm{a}}$ & $6.8 \pm 2.7^{a}$ \\
\hline Erythroblasts & $2.6 \pm 1.1^{\mathrm{a}}$ & $3.0 \pm 1.2^{\mathrm{a}}$ & $3.8 \pm 1.0^{\mathrm{a}}$ & $3.4 \pm 2.0^{\mathrm{a}}$ \\
\hline Erythrocytes & $3.5 \pm 1.1^{\mathrm{a}}$ & $3.5 \pm 0.9^{\mathrm{a}}$ & $3.8 \pm 1.0^{\mathrm{a}}$ & $3.4 \pm 1.2^{\mathrm{a}}$ \\
\hline Lymphoid [\%] & $51.0 \pm 5.3^{\mathrm{a}}$ & $48.7 \pm 4.7^{\mathrm{ab}}$ & $46.3 \pm 8.1^{\mathrm{ab}}$ & $41.0 \pm 7.3^{b}$ \\
\hline Prolymphocytes & $2.5 \pm 1.8^{a}$ & $2.7 \pm 1.2^{\mathrm{a}}$ & $2.3 \pm 1.0^{\mathrm{a}}$ & $3.0 \pm 2.4^{\mathrm{a}}$ \\
\hline Lymphocytes & $47.2 \pm 5.8^{a}$ & $44.6 \pm 4.7^{\mathrm{ab}}$ & $42.3 \pm 8.5^{\mathrm{ab}}$ & $37.5 \pm 7.1^{b}$ \\
\hline Plasmocytes & $1.3 \pm 0.6^{\mathrm{a}}$ & $1.4 \pm 0.6^{\mathrm{a}}$ & $1.8 \pm 0.6^{\mathrm{a}}$ & $1.6 \pm 0.8^{\mathrm{a}}$ \\
\hline Neutrophilic [\%] & $20.1 \pm 1.5^{\mathrm{a}}$ & $20.6 \pm 1.2^{\mathrm{a}}$ & $23.7 \pm 1.6^{b}$ & $26.1 \pm 1.8^{b}$ \\
\hline Myelocytes + metamyelocytes & $15.4 \pm 1.8^{a}$ & $17.9 \pm 1.5^{\mathrm{ab}}$ & $18.7 \pm 2.5^{b}$ & $20.5 \pm 3.0^{b}$ \\
\hline Band + segmented neutrophils & $4.5 \pm 1.4^{\mathrm{ab}}$ & $2.7 \pm 1.4^{\mathrm{a}}$ & $4.9 \pm 1.9^{\mathrm{ab}}$ & $5.6 \pm 2.5^{b}$ \\
\hline Monocytoid [\%] & $2.3 \pm 1.5^{\mathrm{a}}$ & $1.8 \pm 1.1^{\mathrm{a}}$ & $1.4 \pm 0.6^{\mathrm{a}}$ & $1.2 \pm 0.5^{\mathrm{a}}$ \\
\hline Promonocytes & $1.8 \pm 1.1^{\mathrm{a}}$ & $1.3 \pm 0.8^{\mathrm{a}}$ & $1.0 \pm 0.4^{\mathrm{a}}$ & $0.8 \pm 0.4^{\mathrm{a}}$ \\
\hline Monocytes & $0.5 \pm 0.5^{\mathrm{a}}$ & $0.5 \pm 0.5^{\mathrm{a}}$ & $0.4 \pm 0.4^{\mathrm{a}}$ & $0.4 \pm 0.2^{\mathrm{a}}$ \\
\hline Basophilic [\%] & $4.5 \pm 1.5^{\mathrm{a}}$ & $5.3 \pm 1.9^{a}$ & $4.4 \pm 2.7^{\mathrm{a}}$ & $5.1 \pm 2.7^{a}$ \\
\hline Proglanulocytes + metagranulocytes & $2.3 \pm 1.6^{\mathrm{a}}$ & $2.6 \pm 1.1^{\mathrm{a}}$ & $2.4 \pm 1.7^{\mathrm{a}}$ & $3.5 \pm 2.5^{\mathrm{a}}$ \\
\hline Basophils & $1.9 \pm 0.7^{\mathrm{a}}$ & $2.7 \pm 1.6^{\mathrm{a}}$ & $2.0 \pm 0.6^{\mathrm{a}}$ & $1.6 \pm 0.9^{a}$ \\
\hline Eosinophilic [\%] & $0.1 \pm 0.3^{a}$ & $0.2 \pm 0.3^{\mathrm{a}}$ & $0.2 \pm 0.2^{\mathrm{a}}$ & $0.3 \pm 0.3^{\mathrm{a}}$ \\
\hline Thrombocytoid [\%] & $6.2 \pm 1.7^{\mathrm{a}}$ & $5.9 \pm 2.0^{a}$ & $6.0 \pm 2.0^{a}$ & $6.3 \pm 1.9^{a}$ \\
\hline Unclassified cells & $1.3 \pm 0.6^{\mathrm{a}}$ & $1.4 \pm 0.4^{\mathrm{a}}$ & $1.5 \pm 0.6^{\mathrm{a}}$ & $1.6 \pm 0.4^{\mathrm{a}}$ \\
\hline
\end{tabular}




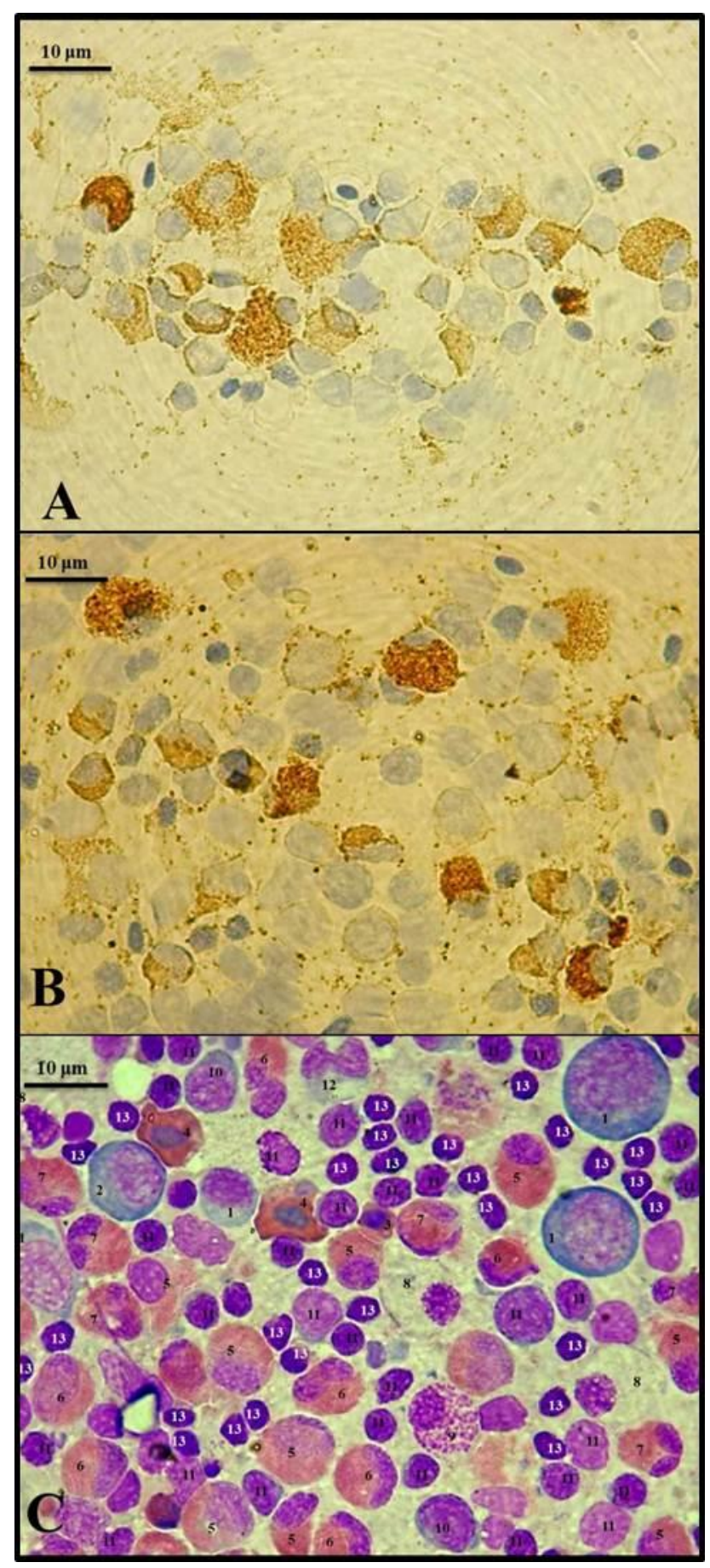

Figure 1. Blood cells in Cyprinus carpio head kidney: (A)—PCNA-positive cells, (B)-Caspase 3-positive cells (stained brownish, immunocytochemical staining), (C)-May-Grünwald and Giemsa solutions (1-blast cell; 2-basophilic erythroblast; 3-young erythrocyte; 4-mature erythrocyte; 5-myelocyte; 6-metamyelocyte; 7-segmented neutrophil; 8-proglanulocyte; 9-mature basophil; 10-prolymphocyte; 11-lymphocyte; 12 - promonocyte; 13-thrombocyte).

\section{Discussion}

Antibiotics are commonly used to control bacterial diseases in both human and veterinary medicine. However, the main source of environmental load is currently intensive livestock production in which antibiotics are used for nontherapeutic purposes (prevention and growth promotion) [42]. Antibiotics used in animals, including oxytetracycline and gentamicin, are not completely absorbed or 
metabolized in the organisms to which they have been administered, and about 30-90\% of the used amount is excreted through urine and feces into the environment [43]. The livestock manure is an important source of environmental contamination with antibiotics [44]. Antibiotics from manures can enter the soil, followed by ground and surface water. The presence of antibiotics in the aquatic environment is worrying because of the possibility of the emergence of resistant bacterial strains including resistant human bacterial pathogens [45], but also in the context of possible toxic effects on aquatic organisms, including fish.

The results of our study showed no significant alterations in peripheral blood parameters of common carp juveniles treated with therapeutic doses of oxytetracycline and gentamicin, except for an increase in the oxidative metabolic activity of phagocytes (NBT) which indicates possible alteration in nonspecific immune response. The data concerning hematological and immune response in fish after antibiotic treatment are scarce and ambiguous. The results obtained by various authors probably depend on antibiotic dosage and the sensitivity of various fish species. A similar effect to that recorded in the present study was reported by Serezli et al. [26], who observed an increase in the frequency of NBT-positive cells in Sparus aurata after oral OTC administration (10 days, $75 \mathrm{mg} / \mathrm{kg}$ ). It was accompanied by a short-term increase in RBC and WBC. On the other hand, Reda et al. [12] reported a slight decrease in the phagocytic index in OTC-treated Oreochromis niloticus, while Maklakova et al. [22] found significant neutropenia and monocytosis in Oncorhynchus mykiss injected with five doses of $20 \mathrm{mg} / \mathrm{kg}$ of OTC. Labeo rohita subjected for 25 days to $80 \mathrm{mg} / \mathrm{L}$ of waterborne OTC showed an increase in $\mathrm{Hb}$ and $\mathrm{Ht}$ accompanied by a decrease in RBC, and an increase in WBC [23]. Omoregie and Oyebanji [20] observed distinct anemia, a significant decrease in $\mathrm{RBC}, \mathrm{Ht}$ and $\mathrm{Hb}$, as well as leukopenia and thrombocytopenia in the same species of fish fed diets containing $0.6-5 \%$ OTC for 8 weeks. Very little data are available on hematological effects of gentamicin in fish. Chen et al. [32] reported anemic response (decrease in Ht and RBC) in Oreochromis niloticus injected with $36 \mathrm{mg} / \mathrm{kg}$ of GEN after 18-20 h.

The results obtained in the present study revealed no significant alterations in AST and ALT activities in fish treated with OTC or GEN, which indicates no hepatotoxic effects of treatments. However, other authors reported that these antibiotics may induce hepatotoxicity. Excessive doses of dietary OTC (100 mg/kg body weight/day orally for 2 weeks) induced an increase in hepatosomatic index (liver enlargement) accompanied by the increase in ALT and AST activities in Oncorhynchus kisutch [27]. Similar results - specifically, increases in the activities of hepatic ALT and AST-were reported by Ambili et al. [23] for Labeo rohita. Reda et al. [12] observed a significant decrease in ALT and increase in AST activity in Oreochromis niloticus fed for 12 weeks with a diet containning $100 \mathrm{mg} / \mathrm{kg}$ of OTC. According to Chen et al. [32], GEN (36 mg/kg) increased activities of ALT and AST.

The results obtained in the present study showed that heamtopoietic tissue was more sensitive to antibiotics compared to the peripheral blood (more significant alterations were observed). The changes observed in antibiotic-treated groups confirm the effect found in peripheral blood (activation of phagocyte response) since the shift from lymphocytes to neutrophils occurred, particularly in the GEN group. This was accompanied by an increased ratio of both proliferative and apoptotic activity of hematopoietic precursors and might have been related to possible GEN-induced tissue lesions. No data are available in the literature concerning the effects of OTC or GEN on hematopoietic tissue composition or activity in fish. The data concerning the effects of various toxic substances on fish hematopoietic tissue showed that cadmium caused a significant increase in the apoptotic rate of hematopoietic precursor cells with only minor increase in the rate of cell proliferation, which resulted in a reduced hematopoietic potential. Short-term exposure to $6.5 \mathrm{mg} / \mathrm{L}$ of cadmium resulted in an increase in percentage of monocytoid cells and eosinophils in the head kidney, while long-term exposure to $0.65 \mathrm{mg} / \mathrm{L}$ induced a significant increase in the frequency of erythroid precursors and thrombocytes in the head kidney [46]. Analysis of head kidney hematopoietic tissue revealed that roundup at concentrations of 0.5 and $5.0 \mathrm{mg} / \mathrm{L}$ caused a significant increase in the rate of cell proliferation accompanied by an increase in the 
frequency of early blast cells. The frequency of monocytoid, eosinophilic, and basophilic lineage cells significantly increased in the herbicide-exposed fish compared to the control [47].

Treating fish with OTC may cause also other pathological alterations, including oxidative stress. Nakano et al. [27] exposed Oncorhynchus kisutch to OTC at the dose of $100 \mathrm{mg} / \mathrm{kg} /$ day for two weeks. They reported that total glutathione content in the liver, muscle and stomach of OTC-treated fish was higher compared to the control. Plasma total glutathione level in OTC-fed fish was also elevated. Rodrigues et al. [16] reported that OTC-exposed Oncorhynchus mykiss exhibited a mild pattern of antioxidant response, with modifications in catalase and glutathione peroxidase activities in the gills, and lipid peroxidation in the liver. Exposure to OTC may lead to the development of histological changes in various fish organs. Rodrigues et al. [13] revealed histopathological changes in Oncorhynchus mykiss after acute $(0.005$ to $50 \mathrm{mg} / \mathrm{L} ; 96 \mathrm{~h})$ and chronic $(0.3125$ to $5 \mu \mathrm{g} / \mathrm{L} ; 28$ days) OTC exposures. They reported progressive disorders in gills after acute exposure and regressive changes after chronic exposure. In the liver, circulatory (e.g., hemorrhage), regressive (e.g., pyknotic nucleus) and progressive (e.g., hypertrophy of hepatocytes) changes were noted, but only after acute exposure. After chronic exposure, inflammatory changes were observed. Rodrigues et al. [48] demonstrated tissue alterations in the gills and liver of Sparus aurata individuals acutely ( $96 \mathrm{~h}$ ) and chronically (28 days) exposed to oxytetracycline $(0.0004-400 \mu \mathrm{g} / \mathrm{L})$. Some circulatory, regressive, progressive, and inflammatory alterations were noted in both tested fish organs in all exposed individuals. On the other hand, Markling et al. [49] showed that even high doses of orally administered OTC did not cause toxic effects in Salvelinus namaycush. In addition, GEN may result in the development of pathological disorders, although the available literature data focus mainly on nephrotoxic effects. Augusto et al. [31] studied the renal response to gentamicin ( $5 \mathrm{mg} / \mathrm{kg}$ and $25 \mathrm{mg} / \mathrm{kg}$ of body weight) in Oreochromis nilotica. Gentamicin exposure induced acute tubular necrosis that peaked in severity at 2 days following intraperitoneal injection of the higher dose and at 4 to 7 days following injection of the lower tested dose. Necrosis after exposure to the higher tested dose was more severe. The authors stated that regeneration of epithelial cells along the basement membrane of damaged tubules and the development of new nephrons were documented. Reimschuessel et al. [29] observed an extensive necrosis in the proximal tubes in Opsanus tau injected with GEN. The results obtained by Hentschel et al. [50] showed a decline in the glomerular filtration rate after exposure of Danio rerio larvae to GEN. On the other hand, Bojarski et al. [3] observed no changes in the reduced glutathione concentration and activity of superoxide dismutase, glutathione peroxidase and catalase measured in GEN-treated Carassius gibelio kidney (5 mg/kg). Moreover, no histological lesions in the kidney were noted.

Our results revealed that therapeutic doses of oxytetracycline and gentamicin caused no significant symptoms of hemato- or hepatotoxicity. However, increased oxidative metabolism of phagocytes, higher hematopoietic precursor cell proliferation and apoptotic rates and higher proportion of neutrophils in hematopoietic tissue of fish treated with antibiotics (particularly gentamicin) compared to the control groups indicate that treatments might have induced slight inflammatory lesions.

Author Contributions: Conceptualization, E.K., B.B. and M.W.; methodology, E.K., B.B. and M.W.; software, E.K. and M.W.; validation, E.K., B.K. and M.W.; formal analysis, E.K., B.B. and M.W.; investigation, E.K., B.B., K.Ł. and M.W.; resources, E.K.; data curation, M.W.; writing-original draft preparation, E.K., B.B. and M.W.; writing-review and editing, E.K., B.B., B.K. and M.W.; visualization, E.K.; supervision, M.W.; project administration, E.K., B.B. and M.W.; funding acquisition, M.W. All authors have read and agreed to the published version of the manuscript.

Funding: This study was funded by the Siedlce University of Natural Sciences and Humanities, Poland (No. 387/14/S).

Conflicts of Interest: The authors declare that they have no conflict of interest.

\section{References}

1. Elia, A.C.; Ciccotelli, V.; Pacini, N.; Dörr, A.J.M.; Gili, M.; Natali, M.; Gasco, L.; Prearo, M.; Abete, M.C. Transferability of oxytetracycline (OTC) from feed to carp muscle and evaluation of the antibiotic effects on antioxidant systems in liver and kidney. Fish Physiol. Biochem. 2014, 40, 1055-1068. [CrossRef] [PubMed] 
2. Leal, J.F.; Santos, E.B.; Esteves, V.I. Oxytetracycline in intensive aquaculture: Water quality during and after its administration, environmental fate, toxicity and bacterial resistance. Rev. Aquac. 2019, 11, 1176-1194. [CrossRef]

3. Bojarski, B.; Batoryna, M.; Bień, M.; Drag-Kozak, E.; Formicki, G.; Jakubiak, M.; Socha, M.; Tombarkiewicz, B. Assessment of gentamicin effect on oxidoreductive balance and microstructure of trunk kidney in Prussian carp (Carassius gibelio). Ann. Wars. Univ. Life Sci. Sggw Anim. Sci. 2019, 58, 115-123. [CrossRef]

4. Hari, R.; Taherunnisa, S.; Raut, S.Y.; Mutalik, S.; Koteshwara, K.B. Challenges in the development of analytical test procedure for aminoglycosides: A critical review. J. Appl. Pharm. Sci. 2019, 9, 145-152.

5. Gbylik-Sikorska, M.; Posyniak, A.; Mitrowska, K.; Gajda, A.; Błądek, T.; Sniegocki, T.; Zmudzki, J. Occurrence of veterinary antibiotics and chemotherapeutics in fresh water, sediment, and fish of the rivers and lakes in Poland. Bull. Vet. Insting. Pulawy 2014, 58, 399-404. [CrossRef]

6. Bojarski, B.; Kot, B.; Witeska, M. Antibacterials in aquatic environment and their toxicity to fish. Pharmaceuticals 2020, 13, 189. [CrossRef]

7. Cabello, F.C.; Godfrey, H.P.; Tomova, A.; Ivanova, L.; Dolz, H.; Millanao, A.; Buschmann, A.H. Antimicrobial use in aquaculture re-examined: Its relevance to antimicrobial resistance and to animal and human health. Environ. Microbiol. 2013, 15, 1917-1942. [CrossRef]

8. Linares, J.F.; Gustafsson, I.; Baquero, F.; Martinez, J.L. Antibiotics as intermicrobial signaling agents instead of weapons. Proc. Natl. Acad. Sci. USA 2006, 103, 19484-19489. [CrossRef]

9. Manage, P.M. Heavy use of antibiotics in aquaculture: Emerging human and animal health problems-A review. Sri Lanka J. Aquat. Sci. 2018, 23, 13-27. [CrossRef]

10. Seyfried, E.E.; Newton, R.J.; Rubert, K.F.; Pedersen, J.A.; McMahon, K.D. Occurrence of tetracycline resistance genes in aquaculture facilities with varying use of oxytetracycline. Microb. Ecol. 2010, 59, 799-807. [CrossRef]

11. Tamminen, M.; Karkman, A.; Lohmus, A.; Muziasari, W.I.; Takasu, H.; Wada, S.; Suzuki, S.; Virta, M. Tetracycline resistance genes persist at aquaculture farms in the absence of selection pressure. Environ. Sci. Technol. 2010, 45, 386-391. [CrossRef]

12. Reda, R.M.; Ibrahim, R.E.; Ahmed, E.N.G.; El-Bouhy, Z.M. Effect of oxytetracycline and florfenicol as growth promoters on the health status of cultured Oreochromis niloticus. Egypt. J. Aquat. Res. 2013, 39, 241-248. [CrossRef]

13. Rodrigues, S.; Antunes, S.C.; Nunes, B.; Correia, A.T. Histological alterations in gills and liver of rainbow trout (Oncorhynchus mykiss) after exposure to the antibiotic oxytetracycline. Environ. Toxicol. Pharmacol. 2017, 53, 164-176. [CrossRef] [PubMed]

14. Grondel, G.L.; Gloudemans, A.G.M.; van Muiswinkel, W.B. The influence of antibiotics on the immune system. I.I. Modulation of fish leukocyte responses in culture. Vet. Immunol. Immunopathol. 1985, 9, 251-260. [CrossRef]

15. Botelho, R.G.; Christofolettib, C.A.; Correiac, J.E.; Ansoarc, Y.; Olindad, R.A.; Tornisielo, V.L. Genotoxic responses of juvenile tilapia (Oreochromis niloticus) exposed to florfenicol and oxytetracycline. Chemosphere 2015, 132, 206-212. [CrossRef] [PubMed]

16. Rodrigues, S.; Antunes, S.C.; Correia, A.T.; Nunes, B. Rainbow trout (Oncorhynchus mykiss) pro-oxidant and genotoxic responses following acute and chronic exposure to the antibiotic oxytetracycline. Ecotoxicology 2017, 26, 104-117. [CrossRef]

17. Pes, T.S.; Saccol, E.M.H.; Londero, E.P.; Bressan, C.A.; Ourique, G.M.; Rizzetti, T.M.; Prestes, O.D.; Zanella, R.; Baldisserotto, B.; Pavanato, M.A. Protective effect of quercetin against oxidative stress induced byoxytetracycline in muscle of silver catfish. Aquaculture 2018, 484, 120-125. [CrossRef]

18. Oliveira, R.; McDonough, S.; Ladewig, J.C.L.; Soares, A.M.V.M.; Nogueira, A.J.A.; Domingues, I. Effects of oxytetracycline and amoxicillin ondevelopment and biomarkers activities of zebrafish (Danio rerio). Environ. Toxicol. Pharmacol. 2013, 36, 903-912. [CrossRef]

19. Barros-Becker, F.; Romero, J.; Pulgar, A.; Feijoo, C.G. Persistent oxytetracycline exposure induces an inflammatory process that improves regenerative capacity in zebrafish larvae. PLoS ONE 2012, 7, e36827. [CrossRef]

20. Omoregie, E.; Oyebanji, S.M. Oxytetracycline-induced blood disorder in juvenile Nile tilapia Oreochromis niloticus (Trewavas). J. World Aquac. Soc. 2002, 33, 377-382. [CrossRef] 
21. Hoseini, S.M.; Yousefi, M. Beneficial effects of thyme (Thymus vulgaris) extract on oxytetracycline-induced stress response, immunosuppression, oxidative stress and enzymatic changes in rainbow trout (Oncorhynchus mykiss). Aquac. Nutr. 2019, 25, 298-309. [CrossRef]

22. Maklakova, M.E.; Kondratieva, I.A.; Mikhailova, E.S.; Stupin, R.V.; Khapchaev, S.H.; Kasumya, A.O. Effect of antibiotics on immunophysiological status and their taste attractiveness for rainbow trout Parasalmo (=Oncorhynchus) mykiss (Salmoniformes, Salmonidae). J. Ichthyol. 2011, 51, 1133-1142. [CrossRef]

23. Ambili, T.R.; Saravanan, M.; Ramesh, M.; Abhijith, D.B.; Poopal, R.K. Toxicological effects of the antibiotic oxytetracycline to an Indian major carp Labeo rohita. Arch. Environ. Contam. Toxicol. 2013, 64, 494-503. [CrossRef] [PubMed]

24. Reda, R.M.; Mahmoud, R.; Selima, K.M.; El-Araby, I.E. Effects of dietary acidifiers on growth, hematology, immune responseand disease resistance of Nile tilapia, Oreochromis niloticus. Fish Shellfish Immunol. 2016, 50, 255-262. [CrossRef]

25. El-Adawy, M.; Abd El-Aziz, M.; El-Shazly Ali, N.G.; Abu El-Magd, M. Dietary propionic acid enhances antibacterial and immunomodulatory effects of oxytetracycline on Nile tilapia, Oreochromis niloticus. Environ. Sci. Pollut. Res. 2018, 25, 34200-34211. [CrossRef] [PubMed]

26. Serezli, R.; Cagirgan, H.; Okumus, I.; Akhan, S.; Balta, F. The effect of oxytetracycline on non-specific immune response in sea bream (Sparus aurata L. 1758). Turk. J. Vet. Anim. Sci. 2005, 29, 31-35.

27. Nakano, T.; Hayashi, S.; Nagamine, N. Effect of excessive doses of oxytetracycline on stress-related biomarker expression in coho salmon. Environ. Sci. Pollut. Res. 2015, 1, 7121-7128. [CrossRef]

28. Cernaro, V.; Sfacteria, A.; Rifici, C.; Marci, F.; Maricchiolo, G.; Lacquaniti, A. Renoprotective effect of erythropoietin in zebrafish after administration of gentamicin: An immunohistochemical study for $\beta$-catenin and c-kit expression. J. Nephrol. 2017, 30, 385-391. [CrossRef]

29. Reimschuessel, R.; Chamie, S.J.; Kinnel, M. Evaluation of gentamicin induced nephrotoxicosis in toadfish. J. Am. Vet. Med. Assoc. 1996, 209, 137-139.

30. Reimschuessel, R.; Williams, D. Development of new nephrons in adult kidneys following gentamicin-induced nephrotoxicity. Ren. Fail. 1995, 17, 101-106. [CrossRef]

31. Augusto, J.; Smith, B.; Smith, S.; Robertson, J.; Reimschuessel, R. Gentamicin-induced nephrotoxicity and nephroneogenesis in Oreochromis nilotica, a tilapian fish. Dis. Aquat. Org. 1996, 26, 49-58. [CrossRef]

32. Chen, C.Y.; Wooster, A.; Bowser, P.R. Comparative blood chemistry and histopathology of tilapia infected with Vibrio vulnificus or Streptococcus iniae or exposed to carbon tetrachloride, gentamicin, or copper sulfate. Aquaculture 2004, 239, 421-443. [CrossRef]

33. Van Trump, W.J.; Coombs, S.; Duncan, K.; McHenry, M.J. Gentamicin is ototoxic to all hair cells in the fish lateral line system. Hear. Res. 2010, 261, 42-50. [CrossRef]

34. Trushenski, J.T.; Aardsma, M.P.; Barry, K.J.; Bowker, J.D.; Jackson, C.J.; Jakaitis, M.; McClure, L.R.; Rombenso, A.N. Oxytetracycline does not cause growth promotion in finfish. J. Anim. Sci. 2018, 96, 1667-1677. [CrossRef]

35. Hassani, M.; Lazaro, R.; Perez, C.; Condon, S.; Pagan, R. Thermostability of oxytetracycline, tetracycline, and doxycycline at ultrahigh temperatures. J. Agric. Food Chem. 2008, 56, 2676-2680. [CrossRef]

36. Jones, J.; Kinnel, M.; Christenson, R.; Reimschuessel, R. Gentamicin concentrations in toadfish and goldfish serum. J. Aquat. Anim. Health 1997, 9, 211-215. [CrossRef]

37. Svobodova, Z.; Pravda, D.; Palackova, J. Unified Methods of Haematological Examination of Fish; Methods No. 20; Research Institute of Fish Culture and Hydrobiology: Vodnany, Czech Republic, 1991.

38. Studnicka, B.; Siwicki, A.K.; Ryba, B. Phagocytic ability of neutrophils in carp (Cyprinus carpio L.). Isr. J. Aquac. Bamidgeh 1985, 37, 123-128.

39. Fijan, N. Morphogenesis of blood cell lineages in channel catfish. J. Fish Biol. 2002, 60, 999-1014. [CrossRef]

40. Fijan, N. Composition of main haematopoietic compartments in normal and bled channel catfish. J. Fish Biol. 2002, 60, 1142-1154. [CrossRef]

41. Kondera, E. Haematopoiesis in the head kidney of common carp (Cyprinus carpio L.): A morphological study. Fish Physiol. Biochem. 2011, 37, 355-362. [CrossRef]

42. Landers, T.F.; Cohen, B.; Wittum, T.E.; Larson, E.L. A review of antibiotic use in food animals: Perspective, policy, and potential. Public Health Rep. 2012, 127, 4-22. [CrossRef] 
43. Awad, Y.M.; Kim, S.C.; El-Azeem, A.M.; Kim, K.H.; Kim, K.R.; Kim, K.; Jeon, C.; Lee, S.S.; Ok, Y.S. Veterinary antibiotics contamination in water, sediment, and soil near a swine manure composting facility. Environ. Earth Sci. 2014, 71, 1433-1440. [CrossRef]

44. Kim, K.R.; Owens, G.; Kwon, S.I.; So, K.H.; Lee, D.B.; Ok, Y.S. Occurrence and environmental fate of veterinary antibiotics in the terrestrial environment. Water Air Soil Pollut. 2011, 214, 163-174. [CrossRef]

45. Kemper, N. Veterinary antibiotics in the aquatic and terrestrial environment. Ecol. Indic. 2008, 8, 1-13. [CrossRef]

46. Kondera, E.; Witeska, M. Cadmium and copper reduce hematopoietic potential in common carp (Cyprinus carpio L.) head kidney. Fish Physiol. Biochem. 2013, 39, 755-764. [CrossRef]

47. Kondera, E.; Teodorczuk, B.; Ługowska, K.; Witeska, M. Effect of glyphosate-based herbicide on hematological and hemopoietic parameters in common carp (Cyprinus carpio L.). Fish Physiol. Biochem. 2018, 44, 1011-1018. [CrossRef]

48. Rodrigues, S.; Antunes, S.C.; Nunes, B.; Correia, A.T. Histopathological effects in gills and liver of Sparus aurata following acute and chronic exposures to erythromycin and oxytetracycline. Environ. Sci. Pollut. Res. 2019, 26, 15481-15495. [CrossRef]

49. Marking, L.L.; Howe, G.E.; Crowther, J.R. Toxicity of erythromycin, oxytetracycline, and tetracycline administered to lake trout in water baths, by injection, or by feeding. Progress. Fish-Cult. 1988, 50, 197-201. [CrossRef]

50. Hentschel, D.M.; Park, K.M.; Cilenti, L.; Zervos, A.S.; Drummond, I.; Bonventre, J.V. Acute renal failure in zebrafish: A novel system to study a complex disease. Am. J. Physiol. Ren. Physiol. 2005, 288, 923-929. [CrossRef]

Publisher's Note: MDPI stays neutral with regard to jurisdictional claims in published maps and institutional affiliations. 